Leoual of JOURNAL OF LEGAL RESERCH

Volume 3, Issue 4 (2021), pp 591-606

P-ISSN: 2715-7172 E-ISSN: 2715-7164

\title{
Perlindungan Hukum Pemegang Lisensi Hak Cipta Menurut Undang-Undang Nomor 28 Tahun 2014 Tentang Hak Cipta*
}

\author{
Aulia Munadiah, ${ }^{1}$ Syafrudin Makmur, ${ }^{2}$ Tresia Elda ${ }^{3}$ \\ Universitas Islam Negeri Syarif Hidayatullah Jakarta
}

$\underline{10.15408 / j \mid r . v 3 i 3.20735}$

\begin{abstract}
The main problem in this thesis is the rampant violations of cinematographic works by several parties illegally, such as what happened in the case in Decision Number 14/Pdt.Sus.Hki/Cipta / 2018 / Pn-Niaga Sby which could harm a license holder of the work.. The purpose of this study was to determine the legal protection of copyright license holders from copyright infringement and to find out the basic analysis of the judges' considerations and decisions in the dispute of Decision Number 14 / Pdt.Sus.Hki/Cipta/2018/Pn-Niaga Sby. This research method uses a normative juridical approach. The juridical normative in this study has two sources of law, namely primary and secondary sources of law. The primary source of law refers to Act No. 28/2014, on the Copyright. The theory used in this research is the theory of legal protection and the theory of intellectual property rights. The results of this study indicate that the regulation regarding legal protection has been regulated in Act No. 28/2014, on the Copyright, the problems in the judge's decision in decision Number 14/Pdt.Sus.Hki/Cipta / 2018 / Pn-Niaga Sby, the panel of judges rejecting the defendant's exception and granting the Plaintiff's Lawsuit. Some forms of evidence used in this case are a license agreement for the work which is the object of violation.

Keywords: Legal Protection, Infringement, Copyright, License Holder.
\end{abstract}

* Received: 20 May 2021, Revision: 06 June 2021, Publish: 15 July 2021.

1 Aulia Munadiah adalah Mahasiswa Alumni Prodi Ilmu Hukum Fakultas Syariah dan Hukum. Universitas Islam Negeri Syarif Hidayatullah Jakarta. Email: auliamunadiahh@gmail.com

${ }^{2}$ Syafrudin Makmur adalah Dosen Fakultas Syariah dan Hukum. Universitas Islam Negeri Syarif Hidayatullah Jakarta. Email: syafrudinmakmur@ymail.com

${ }^{3}$ Tresia Elda adalah Dosen Fakultas Syariah dan Hukum. Universitas Islam Negeri Syarif Hidayatullah Jakarta. Email: tresia.elda@yahoo.com 


\section{A. PENDAHULUAN}

Ilmu pengetahuan dan teknologi di era sekarang ini merupakan hal yang sangat penting untuk menopang kehidupan manusia sebagai ukuran dari sumber daya manusia itu sendiri. Dikarenakan baik atau buruknya seseorang dapat dinilai dari seberapa luas pengetahuan yang dimilikinya. Perkembangan ilmu pengetahuan dan teknologi (IPTEK) semakin hari semakin maju dapat dikatakan salah satu pengaruh dari adanya proses globalisasi. Globalisasi yang dirasakan dalam perkembangan IPTEK memudahkan dalam segala sektor yang ada di dalam kehidupan.

Perkembangan teknologi informasi dipercaya dapat memberikan keuntungan bagi sebuah negara, khususnya dalam pertumbuhan ekonomi. Teknologi informasi telah mengubah perilaku dan gaya hidup masyarakat. ${ }^{4}$ Dengan hadirnya perkembangan teknologi juga mengubah gaya hidup masyarakat dalam ber-interaksi dalam hal berbagi informasi dan komunikasi, sampai dengan memudahkan dalam mendapatkan transportasi. Dengan adanya kemudahan yang didapatkan dari adanya perkembangan teknologi yang pesat tersebut menjadikan semua orang dari seluruh dunia dapat saling terhubung dan menjadi kebutuhan pokok untuk memudahkan semua kegiatan dalam kehidupan. Selain memberikan dampak positif, kemajuan teknologi juga memberikan dampak negatif baik di bidang hukum, ekonomi, politik atau sosial budaya. Misalnya dalam bidang hukum, perlindungan hukum hak cipta menjadi salah satu hal penting yang dibutuhkan untuk menghadapi kejahatan yang terjadi dalam dunia maya.

Teknologi informasi saat ini menjadi pedang bermata dua, karena selain memberikan kontribusi bagi peningkatan kesejahteraan, kemajuan dan peradaban manusia, sekaligus menjadi sarana efektif perbuatan melawan hukum. ${ }^{5}$ Pada bidang ciptaan diperlukan peran Negara yang bertujuan untuk menyeimbangkan antara kepentingan dari si pencipta dengan kepentingan masyarakat. ${ }^{6}$

${ }^{4}$ Hanafizadeh, Payam \& Ghandchi, Samira \& Asgarimehr, Masoud. Impact of Information Technology on Lifestyle: A Literature Review and Classification. International Journal of Virtual Communities and Social Networking, 2017. h. 9.

${ }^{5}$ Mahmuda Pancawisma Febriharini, Eksistensi Hak Atas Kekayaan Intelektual Terhadap Hukum Siber, Jurnal Ilmiah UNTAG Semarang, ISSN: 2302-2752, Vol. 5 No. 1, 2016. h. 15.

${ }^{6}$ Gatot Supramono, Hak Cipta dan Aspek-Aspek Hukumnya, (Jakarta: PT. Rineka Cipta, 2012), h. 3. 
Menurut L. J. Van Aveldoorn, hak adalah hukum yang dihubungkan dengan seseorang manusia atau subjek hukum tertentu dan menjelma menjadi suatu kekuasaan dan suatu hak yang timbul apabila hukum mulai bergerak. ${ }^{7}$ Hak cipta adalah sebuah hak eksklusif yang di dapatkan oleh pencipta setelah melahirkan suatu karya cipta. Hak eksklusif disini karena karya-karya dalam bidang hak cipta merupakan hasil suatu kemampuan intelektual seseorang, maka dari itu hak cipta merupakan sebuah imbalan atas kerja kerasnya tersebut.

Perlindungan hukum terhadap kekayaan pribadi telah menjadi faktor kunci dalam pertumbuhan kapitalisme dan ekonomi pasar bebas. Ada pula yang mengatakan bahwa hukum mengenai perlindungan HKI pada intinya adalah media perjuangan para pihak yang menghendaki penguasaan karya ciptanya melawan pihak lain yang menghendaki pemisahan kekuasaan pencipta dari ciptaannya. ${ }^{8}$ Sebagian besar masyarakat mengakui hak kepemilikkan pribadi, kekayaaan dalam pengertian sebenarnya seperti tanah dan bangunan merupakan kekayaan yang diketahui sebagai kekayaan intelektual. Hukum kekayaan intelektual sangat berperan dalam penyeimbang di era modern seperti ini. Indonesia sebagai negara yang menganut sistem hukum civil law, falsafah perlindungannya adalah kepada pencipta sebagai hak moral, sesuai dengan prinsip perlindungan hak cipta dalam Keppres Nomor 18 Tahun 1997 tentang Pengesahan Berne Convention For The Protection Of Literary And Artistic Works, sebagai hak yang bersifat abadi (perpetual), tidak dapat dicabut (enalinable) serta mengalir sebagai hak warisan pada pencipta, bahkan hak ekonominya dialihkan sekalipun pada perusahaan atau pihak lain. ${ }^{9}$

Undang-Undang Nomor 28 Tahun 2014 tentang Hak Cipta Pasal 40 sudah menegaskan bentuk ciptaan-ciptaan yang dilindungi dan salah satunya adalah karya cipta. Adapun hakim dalam membuat putusan yang baik harus mengandung 3 (tiga) pokok pertimbangan meliputi pertimbangan keadilan filosofis, pertimbangan keadilan sosiologis, dan pertimbangan keadilan yuridis. $^{10}$ Putusan yang diteliti oleh peneliti ialah Putusan Nomor

7 C. S. T, Kansil, Pengantar Ilmu Hukum dan Tata Hukum Indonesia, (Jakarta: Balai Pustaka, 1989), h. 119.

${ }^{8}$ Justin Hughes. The Philosophy of Intellectual Property. Georgetown Law Journal, 77(287): 1988. h. 5.

${ }_{9}^{9}$ Haryono dan Agus Sutono, Pengakuan Dan Perlindungan Hak Cipta Tinjauan Secara Filosofis Dan Teoritis, Jurnal Ilmiah CIVIS, Volume VI, No 2, Juli 2017, h. 56.

${ }^{10}$ Firman Floranta Adonara, Prinsip Kebebasan Hakim dalam Memutus Perkara Sebagai Amanat Konstitusi, Jurnal Konstitusi, Volume 12, Nomor 2, Juni 2015, h.220. 
14/Pdt.Sus.Hki/Cipta/2018/Pn-Niaga Sby yang dalam perkara ini, PT. Inter Sports Marketing sebagai satu-satunya Pemegang dan Penerima Lisensi tayangan siaran FIFA World Cup 2014 Brazil $^{\mathrm{TM}}$ (Piala Dunia FIFA BrazilTM 2014) untuk seluruh Wilayah Republik Indonesia tersebut adalah dibuat dan ditandatanganinya Licence Agreement tertanggal 05 Mei 2011 antara PT. Inter Sports Marketing dengan Federation Internationale De Football Association (FIFA) berkaitan dan/atau berkenaan dengan pelimpahan hak-hak media tertentu juga telah memperjuangkan hak-haknya dimata hukum atas upayaupaya hukum PT. Inter Sports dengan pokok perkara yang sama.

Banyaknnya fenomena kejahatan-kejahatan pelanggaran hak cipta seperti ini sangat membutuhkan kepastian atas perlindungan dan penerapan dari penegak hukum itu sendiri bukan hanya menyangkut kepentingan dari pihak yang dirugikan. Menurut Undang-Undang Nomor 28 Tahun 2014 melainkan telah bertujuan untuk memperoleh suatu pengakuan dari tersangka atau terdakwa. ${ }^{11}$ tentang Hak Cipta pun telah menyebutkan tindakan-tindakan yang masuk kedalam bentuk pelanggaran hak cipta. Pada hakekatnya banyak orang belum mengerti bahwa ada beberapa tindakan mereka yang dapat digolongkan kedalam kejahatan pelanggaran hak cipta.

\section{B. METODE PENELITIAN}

Metode penelitian yang digunakan dalam penelitian ini adalah penelitian normatif. Tipe penelitian yang digunakan dalam penulisan skripsi ini adalah library research (studi kepustakaan) dengan metode penelitian yuridis normatif. Penelitian yuridis normatif adalah metode penelitian hukum yang dilakukan dengan meneliti bahan pustaka atau data sekunder, sepanjang bahan-bahan tersebut mengandung kaidah-kaidah hukum. Pendekatan penelitian yang digunakan dalam penelitian skripsi ini adalah metode pendekatan Undang-Undang (statute approach) yang merujuk pada UndangUndang Nomor 28 Tahun 2014 tentang Hak Cipta dan pendekatan konseptual (conceptual approach) untuk memahami konsep-konsep dari hak cipta dan bentuk-bentuk dari pelanggarannya. Pendekatan penelitian ini juga menggunakan pendekatan kasus (case approach) yang memberikan penerapanpenerapan dari norma atau kaidah hukum yang dilakukan dalam praktek hukum dalam Putusan Nomor 14/Pdt.Sus.Hki/Cipta/2018/Pn-Niaga Sby.

11 Finta Riris Sitorus, Pelanggaran Pengaturan Prinsip Miranda Rule Dalam Hukum Acara Pidana Indonesia, JOM Fakultas Hukum Volume III Nomor 2, Oktober 2016, h. 2-3. 
Perlindungan Hukum Pemegang Lisensi Hak Cipta

Menurut Undang-Undang Nomor 28 Tahun 2014 Tentang Hak Cipta

\section{HASIL TEMUAN DAN PEMBAHASAN}

\section{Putusan dan Pertimbangan Hakim dalam Sengketa}

Sidang musyawarah Majelis Hakim Pengadilan Niaga pada Pengadilan Negeri Surabaya, pada hari kamis tanggal 30 Agustus 2018 , oleh kami,Ari Jiwantara, S.H., M.Hum., sebagai Hakim Ketua Majelis, Sarwedi, S.H., M.H., dan Dwi Winarko, S.H., M.H. masing-masing sebagai Hakim Anggota menyatakan bahwa majelis hakim menolak eksepsi dari tergugat. Apabila berdasarkan dari duduk perkara yang telah diuraikan oleh pengguggat sebelumnya majelis hakim memutuskan untuk mengabulkan gugatan pengguggat dalam point yang pertama, dengan menyatakan bahwa benar sah adanya perjanjian lisensi antara PT. INTER SPORTS MARKETING (penggugat) dengan Federation Internationale de Football Association (FIFA) dan menyatakan bahwa Penggugat adalah satu-satunya Penerima Lisensi dari Federation Internationale De Football Association (FIFA) untuk Media Rights menyiarkan tayangan 2014 FIFA World Cup Brazil di seluruh wilayah Republik Indonesia;

Hakim yang diberikan wewenang dalam perkara putusan ini, memberikan keputusan yang seadil-adilnya tanpa timpang sebelah. Yang mana pada dasarnya Putusan hakim yang baik harus mengandung 3 (tiga) pokok pertimbangan meliputi pertimbangan keadilan filosofis, pertimbangan keadilan sosiologis, dan pertimbangan keadilan yuridis. Bahwasanya suatu pengadilan yang bebas dan tidak dipengaruhi merupakan syarat yang indispensable bagi negara hukum. Bebas berarti tidak ada campur tangan atau turun tangan dari kekuasaan eksekutif dan legislatif dalam menjalankan fungsi judiciary. Ia tidak berarti bahwa ia berhak untuk bertindak sewenang-wenang dalam menjalankan tugasnya, ia "subordinated", terikat pada hukum. ${ }^{12}$

Point selanjutnya dari petitum pengguggat yang dikabulkan oleh majelis hakim ialah, Tergugat telah melakukan Perbuatan Melawan Hukum berupa menayangkan siaran sepakbola 2014 FIFA World Cup Brazil di areal Komersial yaitu di kamar LHOTEL tanpa ijin penggugat - Menghukum Tergugat untuk membayar kerugian materiil sebesar Rp 100.000.000,- ( Seratus Juta Rupiah ) dan kerugian immaterial sebesar Rp. 400.000.000,- ( Empat Ratus Juta Rupiah ) kepada penggugat. - Membebankan beaya yang timbul dalam perkara ini kepada tergugat Konpensi/penggugat rekonpensi sebesar Rp. 6.516.000,- (Enam juta lima ratus enam belas ribu rupiah). -

${ }^{12}$ Oemar Seno Adji, Peradilan Bebas Negara Hukum, Jakarta: Erlangga, 1987,h. 46. 
Putusan tersebut diucapkan pada hari kamis, tanggal 6 September 2018 dalam persidangan terbuka untuk umum oleh Hakim Ketua Majelisdengan didampingi oleh para Hakim Anggota, dibantu Hariyanto, S.H., M.H. Panitera Pengganti , dihadiri Kuasa Penggugat dan Kuasa Tergugat.

Suatu tata hukum dan peradilan tidak bisa dibentuk begitu saja tanpa memperhatikan keadilan, dan adil itu termasuk pengertian hakiki suatu tata hukum dan peradilan, oleh karena itu dalam pembentukan tata hukum dan peradilan haruslah berpedoman pada prinsip-prinsip umum tertentu. ${ }^{13}$ Pokok gugatan penggugat dari duduk perkara yang telah diuraikan oleh penggugg pada dasarnya adalah tentang perbuatan melawan hukum yang dilakukan oleh tergugat berupa penayangan siaran sepak bola piala Dunia tahun 2014 di Brazil tanpa ijin dari penggugat selaku pemegang lisensi dari Federation Internationale De Football Assosiation, dan perbuatan yang mana mengakibatkan kerugian bagi penggugat .

Pengguggat telah melakukan kewajibannya untuk mencatatkan serah terima atau hak ekslusif dari ciptaannya dengan memenuhi syarat sebagaimana tertuang dalam Pasal Pasal 47 ayat ( 2 ) Undang Undang No 19 tahun 2002 tentang hak cipta yang mengatur adanya pencatatan perjanjian lisensi. Penggugat selaku Penerima Lisensi berdasarkan Licence Agreement tersebut, dengan melalui kuasanya Turman M. Panggabean, SH., MH., Konsultan HKI pada Kantor ABSOLUT Patent \& Trade Mark, telah mengajukan Permohonan Pencatatan Lisensi atas Licence Agreement tersebut kepada Direktur Hak Cipta, Direktorat Jenderal Hak Kekayaan Intelektual pada Kementerian Hukum dan Hak Asasi Manusia Republik Indonesia pada tanggal 23 Mei 2014, dan telah diterima dan dicatatkan pada tanggal 23 Mei 2014. Adapun penggugat telah memberikan Sub-Lisensi sebagian dari Hak-Hak Medianya yaitu antara lain hak untuk Penyiaran melalui Televisi Terrestrial antara lain kepada ANTV dan TVOne dan untuk Penyiaran melalui Televisi Berbayar (atau Pay TV Broadcaster) antara lain kepada K-Vision dan VIVASky;

Penggugat dalam upayanya untuk melindungi hak hak media berdasarkan adanya perjanjian lisensi tersebut, telah melakukan sosialiasi, pengumuman, pemberitahuan maupun teguran kepada masyarakat luas terkait Hak-Hak Media atas Siaran 2014 FIFA World Cup Brazil (Piala Dunia FIFA 2014 Brazil) melalui beberapa Media Cetak yang beredar secara nasional. Sebagaimana yang telah dijelaskan diatas bahwa Penggugat adalah satu-

\footnotetext{
${ }^{13}$ Firman Floranta Adonara, Prinsip Kebebasan Hakim dalam Memutus Perkara Sebagai Amanat Konstitusi, Jurnal Konstitusi, Volume 12, Nomor 2, Juni 2015. h.227.
} 
satunya Pemegang dan Penerima Lisensi tayangan siaran Piala Dunia FIFA Brazil 2014 berdasarkan Licence Agreement tertanggal 05 Mei 2011 yang diberikan oleh Federation Internationale De Football Association (FIFA) untuk melaksanakan hak penayangan siaran Piala Dunia FIFA 2014 Brazil untuk kepentingan komersial, dan perjanjian mana telah diajukan Pencatatanya kepada Direktur Hak Cipta, Direktorat Jenderal Hak Kekayaan Intelektual pada Kementerian Hukum dan Hak Asasi Manusia Republik Indonesia dan telah diterima dan dicatatkan pada tanggal 23 Mei 2014, sehingga dengan demikian penggugat berhak untuk mendapatkan perlindungan hukum atas hak-hak Media berupa Siaran 2014 FIFA World Cup Brazil (Piala Dunia FIFA 2014 Brazil)

Majelis hakim berdasarkan uraian tersebut diatas yang menyatakkan memang adanya perjanjian lisensi telah dapat dibuktikan bahwa tergugat dalam melaksanakan penayangan siaran sepak bola piala dunia FIFA Brasil 2014 tidak ada ijin dari penggugat selaku pemegang lisensi hak cipta, sehingga dengan demikian oleh karena tidak terdapat adanya ijin dari penggugat atas penayangan siaran 2014 FIFA World Cup BrazilTM yang dilakukan oleh tergugat tersebut, maka perbuatan tergugat tersebut dikwalifikasikan sebagai perbuatan melawan hukum, sehingga dengan demikian dengan mendasarkan pada Pasal 1365 KUHPerdata, terhadap tergugat tersebut diwajibkan untuk memberikan ganti kerugian kepada penggugat sebagi pihak yang dirugikan ,dimana dalam Pasal 1365 KUHPerdata tersebut telah menegaskan "Setiap Perbuatan Melawan Hukum yang oleh karenanya menimbulkan kerugian pada orang lain, mewajibkan orang yang karena kesalahannya menyebabkan kerugian itu menggantikan kerugian"

Penggugat adalah satu-satunya penerima lisensi dari FIFA untuk media rights menyiarkan tayangan World Cup Tahun 2014 Brazil di seluruh wilayah Republik Indonesia, sehingga yang harus dipertimbangkan dalam perkara a quo adalah masalah "perlindungan hak cipta", yang ternyata dalam perkara a quo Tergugat tanpa izin Penggugat tetap menayangkan siaran tersebut di areal komersial milik Tergugat yang merupakan bagian atau cara daya tarik kepada umum termasuk penyewa kamar milik Tergugat yang merupakan bagian service khusus yang dapat menghasilkan keuntungan kepada Tergugat dan merugikan Penggugat, sehingga perbuatan Tergugat tersebut merupakan Perbuatan Melawan Hukum yaitu melanggar Hak Cipta dan mewajibkan kepada Tergugat untuk membayar ganti rugi sebagaimana yang telah dipertimbangkan oleh Judex Facti yang bahwasanya pertimbanganya telah tepat dan benar serta tidak bertentangan dengan hukum . 


\section{Perlindungan Hukum Pemegang Lisensi dalam Putusan Nomor 14/Pdt.Sus.Hki/Cipta/2018/Pn-Niaga Sby}

Pelanggaran hak cipta sering terjadi di Indonesia, faktor dari terjadinya hal itu disebabkan karena nilai ekonomi yang di dapatkan dari suatu hasil karya ciptaan tidak sedikit nominalnya. Hal tersebut juga terjadi karena adanya dorongan faktor ekonomi yang rendah dan kurangnya pengawasan dari pihak yang berwajib dari adanya pelanggaran-pelanggaran yang terjadi di Indonesia. Undang-Undang Nomor 28 Tahun 2014 tentang Hak Cipta telah mengatur bentuk-bentuk pelanggaran atas hak cipta di Indonesia melalui beberapa Pasal, sebagai berikut:

Pasal 9: (3) Setiap Orang yang tanpa izin Pencipta atau Pemegang Hak Cipta dilarang melakukan Penggandaan dan/atau Penggunaan Secara Komersial Ciptaan.

Pasal 24: Hak ekonomi Produser Fonogram sebagaimana dimaksud pada ayat (1) meliputi hak melaksanakan sendiri, memberikan izin, atau melarang pihak lain untuk melakukan: a. Penggandaan atas Fonogram dengan cara atau bentuk apapun; b. Pendistribusian atas Fonogram asli atau salinannya; c. penyewaan kepada publik atas salinan Fonogram; dan d. penyediaan atas Fonogram dengan atau tanpa kabel yang dapat diakses public.

Pasal 50: Setiap Orang dilarang melakukan Pengumuman, Pendistribusian, atau Komunikasi Ciptaan yang bertentangan dengan moral, agama, kesusilaan, ketertiban umum, atau pertahanan dan keamanan negara.

Jika menarik kesimpulan dari Pasal-Pasal tersebut, terdapat dua jenis pelanggaran hak cipta yang saat ini marak terjadi dimasyarakat, yaitu: (1) Plagiarism atau plagiat yang mempunyai arti sebagai mengutip karya orang lain lalu dimasukkan kedalam ciptaan sendiri atau mengaku-ngaku ciptaan orang lain menjadi ciptaan sendiri. (2) mengambil karya orang lain untuk diperbanyak dan diumumkan sebagaimana aslinya tanpa mengubah bentuk isi, pencipta, dan penerbit/perekam dengan tujuan ingin memperkaya diri sendiri. Perbuatan ini disebut dengan pembajakan yang banyak dilakukan pada ciptaan berupa buku, rekaman audio/video seperti kaset lagu dan gambar $(v c d)$, karena menyangkut dengan masalah a commercial scale. ${ }^{14}$

Seperti halnya dalam Keputusan Presiden Republik Indonesia Nomor 18 Tahun 1997 tentang Pengesahan Berne Convention For The Protection Of

\footnotetext{
${ }^{14}$ Fransin Miranda Lopes, Penegakan Hukum Terhadap Pelanggaran Hak Cipta Di Bidang Musik Dan Lagu, Lex Privatum, Vol.I/No.2/Apr-Jun/2013, hal. 48
} 
Literary And Artistic Works yang mengatur tentang droit moral, yaitu sebuah hak yang dipegang oleh seorang pencipta untuk mengajukan suatu keberatan terhadap setiap perbuatan yang dirasa merugikannya seperti mengubah, mengurangi, atau menambah suatu karya ciptaannya. ${ }^{15}$

Dalam proses mengajukan suatu gugatan diperlukannya sebuah alat bukti yang dapat meyakinkan pihak berwenang bahwa perkara tersebut dapat merugikan dan dapat pantas dijadikan perkara dalam sebuah persidangan. Pengaturan tentang pembuktian telah diatur dalam beberapa Pasal pada Undang-Undang Nomor 28 Tahun 2014 tentang Hak Cipta, yakni:

\section{Pasal 106}

a. Mencegah masuknya barang yang diduga hasil pelanggaran Hak Cipta atau Hak Terkait ke jalur perdagangan;

b. Menarik dari peredaran dan menyita serta menyimpan sebagai alat bukti yang berkaitan dengan pelanggaran Hak Cipta atau Hak Terkait tersebut;

c. Mengamankan barang bukti dan mencegah penghilangannya oleh pelanggar; dan/atau

d. Menghentikan pelanggaran guna mencegah kerugian yang lebih besar.

Pasal tersebut menjelaskan tentang tugas pengadilan niaga yang dapat mengeluarkan penetapan sementara atas adanya permintaan dari pihak pencipta karena telah merasa dirugikan apabila dilihat terjadinya pelanggaran dari karya ciptaannya. Sesuai dengan teori de lege lata yang mana si penggugat dalam kasus ini ialah pencipta mengajukan gugatannya maka si penggugat meminta kepada hakim agar hakim menerapkan ketentuan hukum yang berlaku terhadap peristiwa yang diajukannya, ${ }^{16}$ maka si pengguggat akan membawa Pasal 50 Undang-Undang Nomor 28 Tahun 2014 tentang Hak Cipta yang berbunyi, "Setiap Orang dilarang melakukan Pengumuman, Pendistribusian, atau Komunikasi Ciptaan yang bertentangan dengan moral, agama, kesusilaan, ketertiban umum, atau pertahanan dan keamanan negara" lalu dapat membuktikan adanya sebuah pelanggaran dalam kasusnya tersebut.

${ }^{15}$ Eddy Damian, Hukum Hak Cipta Menurut beberapa konvensi internasional, undangundang hak cipta 1997 dan perlindungannya terhadap buku serta perjanjian penerbitannya, (Bandung: PT. Alumni, 1999), h.61.

16 Prof. Dr. Achmad Ali, Asas-Asas Hukum Pembuktian Perdata, (Jakarta: Kencana 2012), h. 120. 
Hal ini juga disebut sebagai beban pembuktian yng mana ketentuan umum tentang beban pembuktiaan diatur dalam beberapa Pasal yaitu:

Pasal 1865 KUHPerdata yang berbunyi: "Setiap orang yang mendalilkan bahwa ia mempunya sesuatu hak, atau guna meneguhkan haknya sendiri maupun membantah suatu hak orang lain, menunjuk pada suatu peristiwa diwajibkan membuktikan adanya hak atau peristiwa tersebut".

Pasal 163 RIB yang berbunyi: "Barang siapa yang mengatakan mempunnyai barang sesuatu hak, atau menyebutkan sesuatu kejadian untuk meneguhkan haknya itu, atau untuk membantah hak orang lain, maka orang itu harus membuktikan adanya hak itu atau adanya kejadian itu".

Ada beberapa cara dalam proses pengajuan alat bukti yaitu: ${ }^{17}$

1. Mengajukan secara langsung apa yang harus dibuktikan, melalu potongan peristiwa. Alat bukti dalam proses ini menggunakan material evidence atau alat bukti saksi.

2. Menjadikan surat untuk menggambarkan peristiwa yang lampau. Dalam hal ini alat bukti berbentuk tertulis atau surat.

3. Pembuktiaan melalui mendatangkan orang-orang terentu ke muka persidangan, untuk meberikan penjelasan terhadap peristiwa tersebut. Alat bukti ini disebut alat bukti kesaksian atau ketengan ahli.

4. Pembuktian melalui pembuktian hal lain dalam hal membuktikan sesuatu yang sulit untuk dibuktikan. Alat bukti tersbut disebut dengan alat bukti persangkaan-persangkaan.

Dalam Pasal 107 Undang-Undang Nomor 28 Tahun 2014 tentang Hak Cipta terkait syarat-syarat yang harus ditunjukkan oleh pihak pencipta sebagai bukti terjadinya pelanggaran lampiran yang harus dibawa oleh pencipta sebagai bukti, sebagai berikut:

1. Melampirkan bukti kepemilikan Hak Cipta atau Hak Terkait;

2. Melampirkan petunjuk awal terjadinya pelanggaran Hak Cipta atau Hak Terkait;

17 Prof. Dr. Achmad Ali, Asas-Asas Hukum Pembuktian Perdata, (Jakarta: Kencana 2012), h. 78. 
3. Melampirkan keterangan yang jelas mengenai barang dan/atau dokumen yang diminta, dicari, dikumpulkan, atau diamankan untuk keperluan pembuktian;

4. Melampirkan pernyataan adanya kekhawatiran bahwa pihak yang diduga melakukan pelanggaran Hak Cipta atau Hak Terkait akan menghilangkan barang bukti; dan

5. Membayar jaminan yang besaran jumlahnya sebanding dengan nilai barang yang akan dikenai penetapan sementara.

Karena alat bukti mempunyai keterkaitan yang konkret dalam sebuah peristiwa hukum yang bersengketa, maka dari itu lisensi suatu ciptaan sangatlah penting untuk mendukung argumentasi dalam sebuah proses persidangan. Dalam permasalahan ini bentuk alat bukti yang dapat dimasukkan kedalam proses pembuktian diatur dalam Undang-Undang Republik Indonesia Nomor 11 Tahun 2008 Tentang Informasi Dan Transaksi Elektronik Pasal 5 (1) Informasi Elektronik dan/atau Dokumen Elektronik dan/atau hasil cetaknya merupakan alat bukti hukum yang sah.

Penjelasan Pasal 5 Ayat (1) tersebut mengalami perubahan dalam Undang- Nomor 19 Tahun 2016 Tentang Perubahan Atas Undang-Undang Nomor 11 Tahun 2008 Tentang Informasi Dan Transaksi Elektronik yang berbunyi "Bahwa keberadaan Informasi Elektronik danlatau Dokumen Elektronik mengikat dan diakui sebagai alat bukti yang sah untuk memberikan kepastian hukum terhadap Penyelenggaraan Sistem Elektronik dan Transaksi Elektronik, terutama dalam pembuktian dan hal yang berkaitan dengan perbuatan hukum yang dilakukan melalui Sistem Elektronik."18

Tujuan dari adanya kegiatan pembuktian dalam sebuah persidangan bagi masing-masing pihak adalah sebagai berikut: ${ }^{19}$

1. Bagi penuntut umum, tujuan pembuktian merupakan sebuah usaha untuk meyakinkan hakim, alat bukti menjadi faktor pendukung dari argumentasi dalam surat dakwaan seorang penuntut umum.

2. Bagi terdakwa atau penasihat hukum, tujuan pembuktian adalah untuk meyakinkan hakim bahwa seorang terdakwa berhak untuk dibebaskan dari suatu tuntutan hukum.

18 Undang-Undang Republik Indonesia Nomor 19 Tahun 2016 Tentang Informasi Dan Transaksi Elektronik

19 Alfitrah, Hukum Pembuktian Dalam Beracara Pidana, Perdata, Dan Korupai Di Indonesia, (Jakarta: Raih Asa Sukses,2011), h.25.

Journal of Legal Research. Volume 3, Nomor 4 (2021). ISSN: 2715-7172. E-ISSN: 2715-7164 - 601 
3. Bagi hakim, tujuan pembuktiaan adalah sebagai fondasi atas dasar untuk membuat keputusan. Karena pada dasarnya, pembuktiaan elektronik juga memberikan pembuktian bebas kepada hakim sebagai bahan pertimbangan dalam proses pemeriksaan perkara.

Tujuan dari adanya perlindungan Hak Cipta merupakan untuk mencegah adanya pihak lain yang merugikan dengan memanfaatkan karya cipta seorang pencipta tanpa izin dengan tujuan komersial. ${ }^{20}$ Karena Hukum berfungsi untuk melakukan perlindungan kepentingan dr subjek hukum, agar kepentingan subjek hukum dapat terlindungi, hukum harus dilaksanakan. ${ }^{21}$ Adapun yang dimaksud dengan pelindungan hukum adalah memberikan pengayoman kepada hak asasi manusia yang dirugikan. Dirugikan dalam hal ini yaitu terlanggarnya suatu hak daripada subjek hukum oleh subjek hukum lainya sehingga menghasilkan hilangnya hak perlindungan hukum dari si subjek hukum tersebut. ${ }^{22}$

Sesuai dengan Keputusan Presiden Republik Indonesia Nomor 18 Tahun 1997 tentang Pengesahan Berne Convention for The Protection Of Literary And Artistic Works dalam Pasal 2 ayat (6) Konvensi Bern, bahwa perlindungan dalam karya sinematografi berlaku untuk kepentingan seorang pencipta yang akan mendapatkan perlindungan dari semua negara persatuan. "The works mentioned in this Article shall enjoy protection in all countries of the Union. This protection shall operate for the benefit of the author and his successors in title."

Dalam Indonesia sendiri sudah cukup pengaturan yang menegaskan bahwa karya sinematografi yang tercatat dalam Direktorat Jenderal Kekayaan Intelektual dijamin perlindungan hukumnya oleh negara. Hal tersebut yang menjadi penting bagi para pencipta karya untuk mencatatkan karya mereka untuk mendapatkan sertifikat keterangan hak cipta guna menjadi bukti apabila terjadinya sengketa dikemudian harinya.

Hak ekonomi yang diterima oleh pemegang hak cipta diatur dalam Undang-Undang Nomor 28 Tahun 2014 tentang Hak Cipta, yaitu:

${ }^{20}$ Nanan Isnaina, Perlindungan Hukum Terhadap Pemegang Hak Cipta Terkait Pembajakan Sinematografi Di Aplikasi Telegram, Dinamika, Jurnal Ilmiah Ilmu Hukum, Volume 27, Nomor 7, Januari 2021, h. 995.

21 Sudikno Mertokusumo, Mengenal Hukum (Suatu Pengantar), (Yogyakarta: Liberty 1991), h.134.

22 Satjipto Rahardjo, Penyelengaraan Keadilan dalam Masyarakat yang Sedang Berubah, (Bandung: Jurnal Masalah Hukum, 1993), h. 6. 
Pasal 9: (1) Pencipta atau Pemegang Hak Cipta sebagaimana dimaksud dalam Pasal 8 memiliki hak ekonomi untuk melakukan: a). Penerbitan Ciptaan; b). Penggandaan Ciptaan dalam segala bentuknya; c). Penerjemahan Ciptaan; d). Pengadaptasian, pengaransemenan, atau pentransformasian Ciptaan; e). Pendistribusian Ciptaan atau salinannya; f). Pertunjukan Ciptaan; g). Pengumuman Ciptaan; h). Komunikasi Ciptaan; dan i). Penyewaan Ciptaan.

Perlindungan hukum bagi hak ekonomi dalam hak cipta karya sinematografi sudah diatur dalam dua Pasal, sebagai berikut: ${ }^{23}$

Pasal 59: (2) Pelindungan Hak Cipta atas Ciptaan berupa karya seni terapan berlaku selama 25 (dua puluh lima) tahun sejak pertama kali dilakukan Pengumuman.

Pasal 63: (1). Pelindungan hak ekonomi bagi:

a. Pelaku Pertunjukan, berlaku selama 50 (lima puluh) tahun sejak pertunjukannya difiksasi dalam Fonogram atau audiovisual;

b. Produser Fonogram, berlaku selama 50 (lima puluh) tahun sejak Fonogramnya difiksasi; dan

c. Lembaga Penyiaran, berlaku selama 20 (dua puluh) tahun sejak karya siarannya pertama kali disiarkan.

Jika diperhatikan, Undang-Undang Nomor 28 Tahun 2014 tentang Hak Cipta telah mengakomodir terkait perlindungan dari pencipta karya sinematografi, karena dalam perkembangannya yang melewati beberapa perubahan, Undang-Undang ini merupakan suatu gebrakan dari Indonesia untuk menunjukan partisipasinya dalam perlindungan hak cipta, dengan berpedoman kepada ketentuan-ketentuan internasional yang sudah ada seperti Berne Convention tahun 1886 dan Trade Related aspects of intellectual property rights (TRIPs). Namun, dengan banyaknya praktek-praktek pelanggaran hak cipta dalam karya sinematografi menunjukan bahwa penegakan hukum terkait hak cipta belum dilakukan secara maksimal.

Pada hakikatnya ada dua bentuk perlindungan hukum yaitu, preventif dan represif:

Pertama; Perlindungan Hukum Preventif. Perlindungan Hukum Preventif adalah perlindungan yang diberikan oleh pemerintah untuk mencegah terjadinya pelangaran. Hal ini terdapat dalam peraturan perundang undangan dengan maksud untuk mencegah suatu pelanggaran serta

${ }^{23}$ Undang-Undang Republik Indonesia Nomor 28 Tahun 2014 Tentang Hak Cipta Journal of Legal Research. Volume 3, Nomor 4 (2021). ISSN: 2715-7172. E-ISSN: 2715-7164 - 603 
memberikan rambu-rambu atau batasanbatasan dalam melakukan sutu kewajiban. ${ }^{24}$ Tujuan dari adanya perlindungan ini ialah mencegah terjadinya sebuah sengketa dikemudian hari. Dalam perlindungan hak cipta karya sinematografi, perlindungan hukum preventif berada dalam Undang-Undang Nomor 28 Tahun 2014 tentang Hak Cipta yaitu: Pasal 54 yang menyatakan bahwa untuk mencegah pelanggaran Hak Cipta dan Hak Terkait melalui sarana berbasis teknologi informasi, Pemerintah berwenang melakukan:

a. Pengawasan terhadap pembuatan dan penyebarluasan konten pelanggaran Hak Cipta dan Hak Terkait;

b. Kerja sama dan koordinasi dengan berbagai pihak, baik dalam maupun luar negeri dalam pencegahan pembuatan dan penyebarluasan konten pelanggaran Hak Cipta dan Hak Terkait; dan

c. Pengawasan terhadap tindakan perekaman dengan menggunakan media apapun terhadap Ciptaan dan produk Hak Terkait di tempat pertunjukan.

Kedua; Perlindungan Hukum Represif. Perlindungan Hukum Represif adalah perlindungan hukum yang diberikan berupa sanksi seperti denda, penjara, kurungan ataupun hukuman tambahan yang diberikan apabila sudah terjadi sengketa atau telah dilakukan suatu pelanggaran. ${ }^{25}$ Dalam bentuk perlindungan ini ditandai dengan sanksi-sanksi yang telah ditegaskan tercantum dalam Undang-Undang Nomor 28 Tahun 2014 tentang Hak Cipta dengan tujuan menyelesaikan sengketa guna melindungi kepentingan subjeksubjek hukum, dan untuk menghindari overlapping dalam sebuah kepentingan satu pihak dengan pihak lain sehingga negara memberi batasan tersebut.

\section{KESIMPULAN}

Putusan Hakim Pada Putusan Nomor 14/Pdt.Sus.Hki/Cipta/2018/PnNiaga Sby, majelis hakim menolak eksepsi dari tergugat dan mengabulkan Gugatan Penggugat untuk sebagian bentuk alat bukti yang dapat dimasukkan kedalam proses pembuktian diatur dalam Undang-Undang Republik Indonesia Nomor 11 Tahun 2008 Tentang Informasi Dan Transaksi Elektronik Pasal 5 (1) Informasi Elektronik dan/atau Dokumen Elektronik dan/atau hasil cetaknya

24 Muchsin, Perlindungan dan Kepastian Hukum Bagi Investor Indonesia, (Surakarta: Jurnal Magister FH UNS, 2003), h.14.

${ }^{25}$ Phillipus M. Hadjon, Perlindungan Hukum Bagi Rakyat Indonesia, (Surabaya: PT. Bina Ilmu, 1987). h. 75. 
merupakan alat bukti hukum yang sah. Maka dalam kasus telegram, lampiran bukti yang dapat dijadikan dalam pembuktian merupakan sebuah tangkapan layar dari keberadaan akun yang menyediakan video film ilegal dan lisensi atas karya ciptaan yang dijadikan objek pelanggaran.

Pada hakikatnya ada dua bentuk perlindungan hukum yaitu, preventif dan represif. Perlindungan Hukum Preventif adalah perlindungan yang diberikan oleh pemerintah untuk mencegah terjadinya pelangaran, seperti yang tercantum dalam Pasal 54 Undang-Undang Nomor 28 Tahun 2014 tentang Hak Cipta. Sedangkan, perlindungan hukum Represif adalah perlindungan hukum yang diberikan berupa sanksi, yang telah ditegaskan tercantum dalam Pasal 112-114, Pasal 117 dan Pasal 119 Undang-Undang Nomor 28 Tahun 2014 tentang Hak Cipta. Perihal hak cipta karya sinematografi, perlindungan hukum yang harus diperhatikan datang dari hak ekonomi dari pencipta yang seringkali diugikan karena adanya pelanggaran-pelanggaran dari pihak yang tidak bertanggung jawab. Hak ekonomi yang diterima oleh pemegang hak cipta diatur dalam Pasal 9 Undang-Undang Nomor 28 Tahun 2014 tentang Hak Cipta. Adapun perlindungan hukum bagi hak ekonomi dalam hak cipta karya sinematografi sudah diatur dalam Pasal 59 ayat (2) dan Pasal 63.

\section{REFERENSI:}

Adji. Oemar Seno, 1987, Peradilan Bebas Negara Hukum, Jakarta: Erlangga.

Al-Khudairi, Zainab. 1987. Filsafat Sejarah Ibnu Khaldun, Bandung: Pustaka.

Ali, Achmad, 2012, Asas-Asas Hukum Pembuktian Perdata, Jakarta: Kencana.

Alfitrah, 2018. Hukum pembuktian dalam beracara pidana, perdata, dan korupsi di Indonesia Edisi Revisi, Jakarta: Raih Asa Sukses.

Angrayni. Lysa, 2014, Diktat Pengantar Ilmu Hukum, Riau: Suska Press.

Damian, Eddy. 1999. Hukum Hak Cipta Menumt Bebcrapa Konvens1 Intemasional. Undang-undang Hak Cipta 1997 dan Pcrlindungannva tcrhadap Buku serta Perjanjian Penerbitannya, Bandung: PT. Alumni.

Hadjon, Phillipus M. 1987, Perlindungan Hukum Bagi Rakyat Indonesia, Surabaya: PT. Bina Ilmu.

Joice. Craig, William Patry, Marsh Leaffer dan Peter Taszi, 1998, Copyright Law - Casebook Series, Forth Edition, New York, Matthew Bender \& Company Incorporated. 
Kansil C. S. T, 1989. Pengantar Ilmu Hukum dan Tata Hukum Indonesia, Jakarta: Balai Pustaka.

Keraf. Sonny, 1997, Hukum Kodrat dan Teori Hak Milik Pribadi, Yogyakarta Kanisius.

Melfa, Wendy. dan Siddiq, Solihin. 2007. Paradigma Pengembangan Mayarakat Islam; Studi Epistemologis Pemikiran Ibnu Khaldun, Lampung: Matakata.

Mertokusumo, Sudikno, 1991, Mengenal Hukum (Suatu Pengantar), Yogyakarta: Liberty.

Raharjo, Satjipto. 2000. Ilmu Hukum, Bandung: PT. Citra Aditya Bakti.

Rahardjo, Satjipto, 1993, Penyelengaraan Keadilan dalam Masyarakat yang Sedang Berubah, Bandung: Jurnal Masalah Hukum.

Rahardjo, Satjipro. 2003. Sisi-Sisi Lain dari Hukum di Indonesia, Jakarta: Kompas.

Adonara. Firman Floranta, Prinsip Kebebasan Hakim dalam Memutus Perkara Sebagai Amanat Konstitusi, Jurnal Konstitusi, Volume 12, Nomor 2, Juni 2015.

Asiah, Nur. Hak Asasi Manusia Perspektif Hukum Islam, Jurnal Syariah Dan Hukum diktum Volume 15, Nomor 1, Juni 2017.

Haryono dan Agus Sutono, Pengakuan Dan Perlindungan Hak Cipta Tinjauan Secara Filosofis Dan Teoritis, Jurnal Ilmiah CIVIS, Volume VI, No 2, Juli 2017.

Isnaina, Nanan, Perlindungan Hukum Terhadap Pemegang Hak Cipta Terkait Pembajakan Sinematografi Di Aplikasi Telegram, Dinamika, Jurnal Ilmiah Ilmu Hukum, Volume 27, Nomor 7.

Lopes, Fransin Miranda, Penegakan Hukum Terhadap Pelanggaran Hak Cipta Di Bidang Musik Dan Lagu, Lex Privatum, Vol.I/No.2/AprJun/2013

Porta, Rafael La., "Investor Protection and Cororate Governance; Journal of Financial Economics", No. 58, Oktober 1999.

Muchsin, Perlindungan dan Kepastian Hukum bagi Investor di Indonesia, Surakarta: Disertasi S2 Fakultas Hukum, Universitas Sebelas Maret, 2003.

Setiono, Rule of Law, Surakarta: Disertasi S2 Fakultas Hukum, Universitas Sebelas Maret, 2004. 